Arch. hist. jap. Vol. 14, n. 4 (June 1958).

P. $485-494$.

Dept. of Anat., School of Med., Hirosaki Univ. (Prof. V. MIZUHIRA) and

Dept. of Dentistry, Hirosaki Univ. Hosp.

\title{
On the Structure of the Matrix Surrounding Lateral Branches of Dentinal Tubules.
}

象牙細管倒枝末梢部の構遀について.

Goro HIRAI, Shunji HIRAI and Mitsuo KOHARA

平茾五郎，平井俊児，小原三罗。

(Received May 24, 1958.)

The human dentin is permeated by a number of dentinal fibers, which are considered to be in close connection with the metabolism of the dentin, but which have been up to now the object of arguments how they, being organic, functionally relate with inorganic matrix. From this point of view, the lateral branches of the dentinal fibers seem to play an important role upon the function, but any structural characteristic to prove it has not been found around them.

Since it is hardly considerable that lateral branches of the dentinal fiber have any metabolic interrelations with thoroughly calcified matrix of the dentin, it seems possible to have certain structures surrounding them.

MIZUHIRA (1956), attentively studying undecalcified ground sections, found by chance globular structures in the matrix surrounding lateral branches of dentinal tubules on a relatively over-etched ground section. The authors were recommended to investigate the nature and the significance of this structure, and after examining many ground and decalcified sections with variable staining methods, seemed to have reached certain conclusions to explain the nature and significance of the above structure.

\section{Material and Methods.}

The normal teeth of adult human subjects were fixed in $10 \%$ neutral formalin. Some teeth, after decalcification in $5 \%$ nitric acid, imbedded in paraffin, followed by sectioning, or frozen-sectioned. Others were without preliminary decalcification ground to obtain thin sections which were then etched with $1 / 10 \mathrm{~N} \mathrm{HCl}$ for 30 seconds to 2 minutes and stained histologically.

The authors' routine staining methods were as follows: hematoxyline, SCHMORL's thionin-picric acid (1928), MANN's methyl blue-eosin (ROMEIS 1948) and CASON's MALLORY.HEIDENHAIN staining (1950). Other than routine methods is to be described hereafter.

Metachromatic staining. There is a variety of methods using toluidine blue for the histochemical purpose. The authors stained undecalcified ground sections or decalcified paraffin sections with $0.5 \%$ aqueous toluidine blue for $4-6$ hours, rinsed 
and examined the section immediately in water under strong yellowish light.

Potassium permanganate staining. Potassium permanganate has a strong affinity to the dentinal fiber, and additional staining with alkaline methylen blue ( $\mathrm{pH} \mathrm{10)}$ gives a clear view of it (McCONNAILL 1955). Without after-staining tan colour of permanganate conceals the structural detail.

Periodic acid SCHIFF test. WISLOCKI and SOGNNAES (1950) reported that the matrix and the fiber of the dentin gave intense positive reaction with periodic acid SCHIFF test. Metachromasia and PAS positive reaction suggests the presence of mucopolysaccharides. This technique, however, is so violently acidic to the ground section that is applicable to the decalcified section only.

Demonstration of sulfhydril groups. SOGNNAES (1955) has shown the presence of sulfhydril groups in the predentin. As the dentin calcifies, this reaction dissappears. Conversely, if sulfhydril groups are present somewhere in dentin, possibly that place is of younger dentin. For the purpose of demonstrating sulf hydril groups, BARNETT and SELIGMAN method $(1952,1954)$ is desirable, but regretfully as that reagents are not obtainable at the moment, the authors used the technique derived by CHËVREMONT and FREDERIC (1943). This method also could not be used in the ground section but in the decalcified section only.

VON KOSSA's silver method. This technique is an indirect proof for the presence of calcium, combining $\mathrm{PO}_{4}{ }^{\prime \prime \prime}$ of calcium phosphate with $\mathrm{Ag}^{*}$ of silver nitrate, and easily dissociable calcium compound makes the reaction positive. The authors, according to the description of GOMORI (1952), immersed the ground section in $1 \%$ silver nitrate solution for 10 minutes in a dark room, thoroughly rinsed in distilled water for at least a quarter of an hour, reduced with a ten times diluted commercial developer and fixed with $5 \%$ sodium thiosulphate. VON KOSSA's original procedure was less useful for the amount of precipitates of unspecific silver particles.

Allizarin red $S$ staining. This method depends upon the formation of red calcium lake with readily dissociable calcium compounds. As to the sensitivity many authors agreed to be low as described by PEARSE (1953), but DAHL (1952) improved the technique by the adjustment of hydrogen ion concentration so that both the sensitivity and the specificity might possess a sufficient result. As this method, however, seems to be much complicated, HARMS (1957) acquired an equal result with a simplified procedure, that is, to stain alcohol-fixed sections with $1 \%$ allizarin red $\mathrm{S}$ in a sufficient $0.1 \%$ ammonia water to give the final $\mathrm{pH} 6.36-6.40$ for 1 minute. Differentiation with $1 / 1000 \mathrm{M} \mathrm{HCl}$ in $95 \%$ alcohol is optional.

Sudan black B staining. As LISON (1953) described, the authors stained with saturated sudan black $B$ in $70 \%$ alcohol for $7-30$ minutes, rinsed in $70 \%$ alcohol and mount in glycerin jelly or APATHY's gum syrup.

Other optical investigations. Besides section staining, the authors employed phase contrast and polarizing microscopic observations. To investigate the three dimensional construction of the specimen, the authors also employed the stereographic examination. 


\section{Observations.}

\section{A. Phase contrast microscopic observation.}

Unstained ground sections etched with $1 / 10 \mathrm{~N} \mathrm{HCl}$ from 30 seconds to 2 minutes, were examined under phase contrast microscope with the result that lateral branches of dentinal tubules seemed to be swollen especially at these distal ends. When mounted in balsam $\left(\mathrm{N}_{\mathrm{D}} \fallingdotseq 1.52\right)$, this gloubular structures look to be dark at bright contrast lens and bright at dark contrast one. If mounted another medium, e. g. Bioleit $\left(\mathrm{ND}_{\mathrm{D}}=1.409\right)$, better results could be obtained.

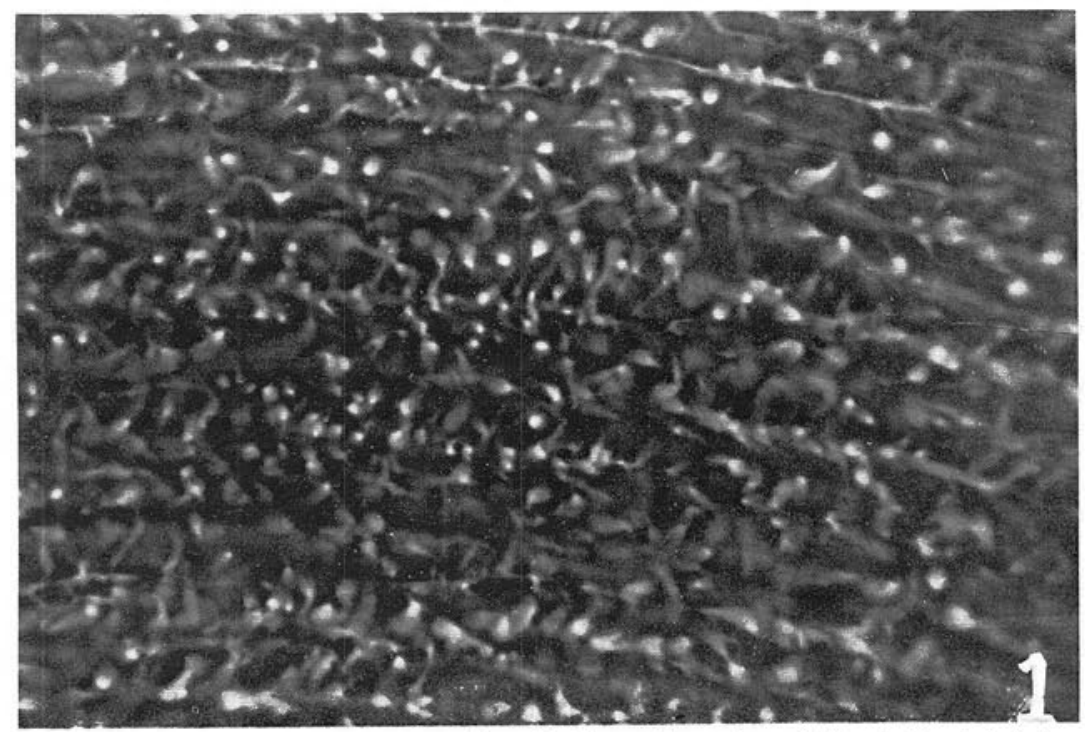

Fig. 1. Globular structures surrounding the lateral branches of the dentinal tubules. The area is near by the dentino-enamel junction. Ground section etched with $1 / 10 \mathrm{~N}$ $\mathrm{HCl}$ for 30 seconds. Phase contrast method. $\times 800$.

This structures were observed to be globular when they were more or less distant from dentinal tubules, and to be rod- or pear-shaped when they were contact. Most numerous sites were in peripheral zone of tooth crown, and the number was gradually reduced towards the neck. In tooth root, there was in many cases hardly observable, but in other cases good many globular structures were present. In general, in the crown and the periphery where abundant in interglobular spaces the above structures were numerous. In secondary and transparent dentin, those were never found. At the dentino-enamel junction more or less observable, though in this case phase contrast method was less effective than staining methods for a lack of contrast with surrounding dentinal matrix.

\section{B. Observations with histological and histochemical staining technique.}

When examined a hematoxylin stained ground section the globular structures similarly appeared as observed under phase contrast method, although these were not perceivable when unetched. With MALLORY-HEIDENHAIN procedure, these were coloured reddish. Decalcified sections revealed no structure on the periphery 


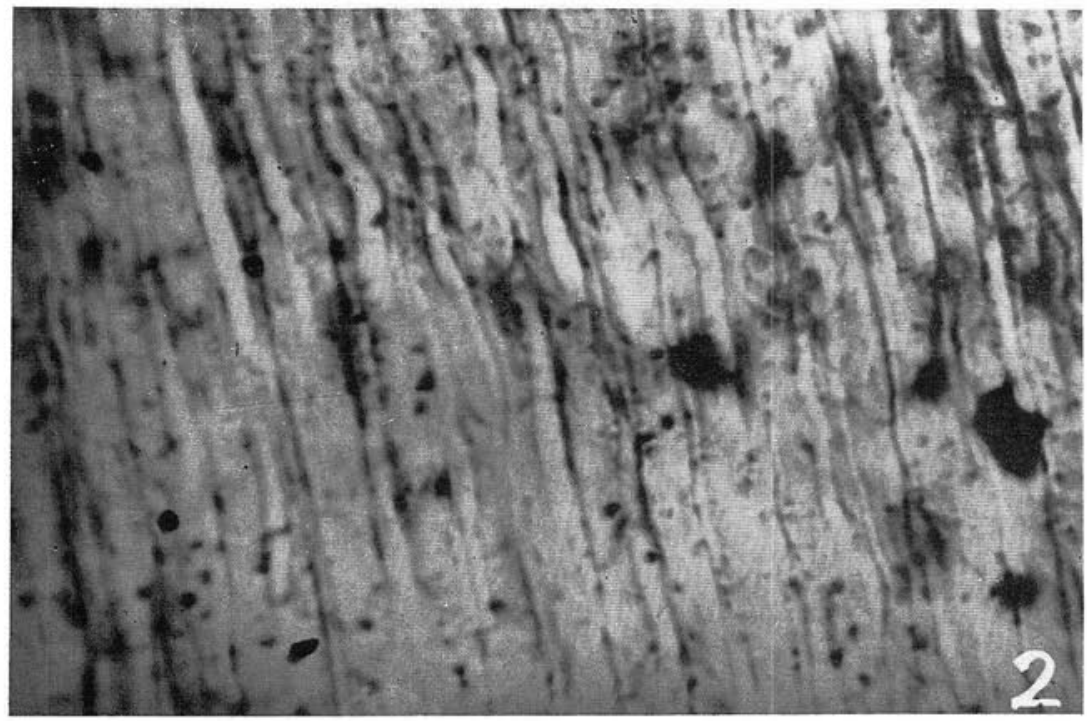

Fig. 2. Globular structures are apparently smaller as covered by the intense background staining. CASON's MALLORY-HEIDENHAIN staining after etching. Magnification same as above.

of branches of dentinal tubules. Other stainig technique such as MANN's or SCHMORL's procedure gave the result quite unsatisfactorily. Anyhow these results permitted the autors to conclude that the globular structures appeared only when the ground section was etched with acid, and therefore, might have some variations on the chmical or physical composition of the mineralized dentin matrix.

Presence of low crystallized calcium salts in the dentinal matrix. Either von KOSSA's and allizarin red S staining method made as well the wall of tubules and the interglobular spaces as the globular structures on the distal ends of tubular branches to demonstrate clearly. The latter method seemed better. The results show that the periphery of tubular branches is low crystallized and more reactive, as MeLEAN and BLOOM (1940) and recently HELLER-STEINBERG (1951) studied the reaction of teeth with silver nitrate embryologically and experimentally. The authors consider the allizarin red $\mathrm{S}$ method to be more sensitive one than the silver method to derive the above conclusion from.

Relationship with the dentinal fibers. The method to demonstrate dentinal fibers as well as globular structures at the same time was a potassium permanganate and additional alkaline methylen blue method, which stained the dentinal fiber deep blue and globular structure metachromatically. At higher magnifications branches of dentinal fibers penetrated into the globular structures. From the colour difference it was no more doubtful that the globular structures were by no means the swelling of dentinal fibers but the structure of the matrix surrounding tubular branches.

Relationship with the organic matrix of the dentin. Periodic acid SCHIFF test 


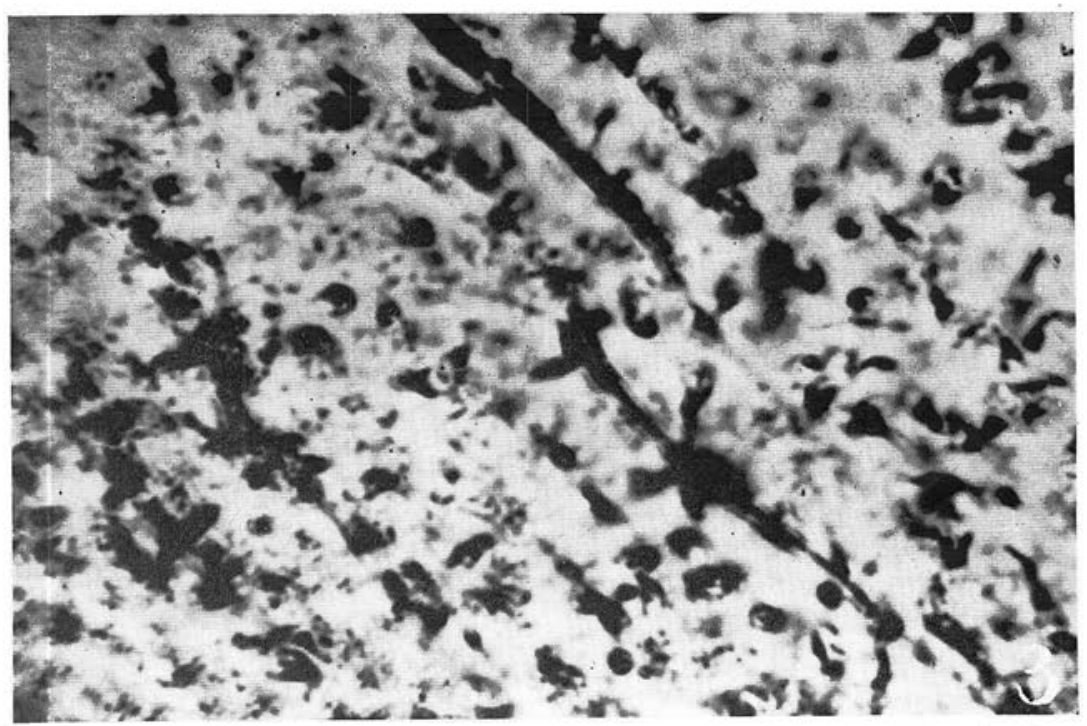

Fig. 3. VON KOSSA's silver method. Ground section with etching. Magnification same as above.

was performed for the purpose of demonstrating mucopolysaccharides in the matrix of dentin, without any result to assume certain structure surrounding tubular branches. There was no trace of sulfhydril groups, and no site to give metachromatic colour with toluidine blue in decalcified sections. In ground sections, however, the globular structures gave faint metachromatic staining with toluidine blue. These results failed the authors to demonstrate any morphological changes of the organic constituents of the dentinal matrix equivalent to the globular structures seen in a ground section.

Presence of lipids in the matrix of dentin. The globular structures were very marked when stained ground sections with sudan black B followed etching with hydrochloric acid. Treatment of specimen with absolute alcohol for a certain minutes before staining never precluded the precipitation of the dye. The authors confirmed that the positive substance there might perhaps be rather phospholipids than neutral lipids.

\section{Polarizing microscopic examination.}

Ground sections were examined under polarizing microscope after treatment with acid. The globular structures had the same axis as the surroundings, namely, at the extinction and diagonal position the structures had not been distinguishable as it was covered with an intrinsic birefringence of the surroundings. If deviate a little to either direction from these positions, the structures reappeared for being seen relatively darker than the surroundings. This fact declares that the structures are less calcified than the environments.

\section{Stereographic phase contrast microscopy.}

Stereophotomicrographs are helpful in showing the third dimension of a speci- 


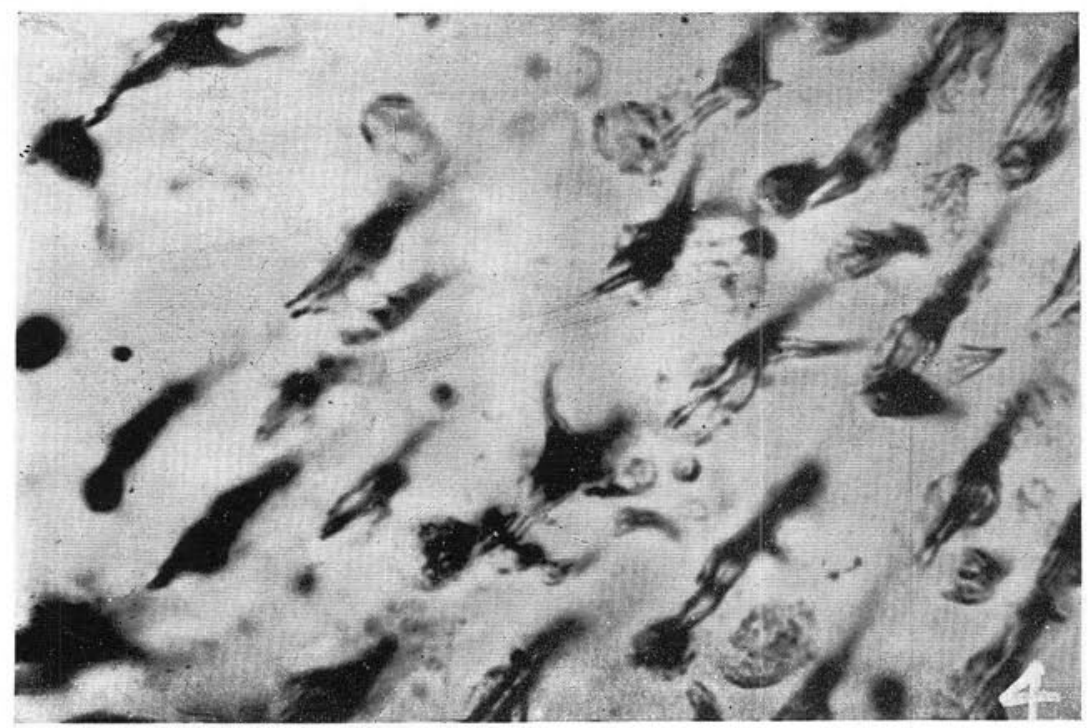

Fig. 4. Sudan black B staining. Ground section with etching. $\times 2000$.

men and made by half aperture method described by RICHARDS (1951) and improved by MIZUHIRA (1058). A piece of metallic diaphragm is placed to cover onehalf of the annulus, and the first picture made. The annulus is rotated $180^{\circ}$, and the second exposure is made. The two exposures of the pair were processed together and mounted so that the corresponding points are about 2.5 inches apart and so that horizontal lines in each are in line to avoid tilt. The mounted pair was fused on direct observation. The result was that the structure was not superficial but three dimensional one.

\section{Discussion.}

The authors could not consider to have fully described about the functional morphology of the branches of dentinal tubules from the litarature. Sir C.S. TOMES (1923) has described that the course of the tubes is sometimes apparently interrupted by a small interglobular space, which the authors could not tell whether it was the globular structures in our present investigation, or not. The globular structures, however, are never small interglobular spaces formed by imperfect spherical calcification. The reason is shown in former figures. Other representative text books as ORBAN (1953), FUJITA (1957) etc. fail to describe in details about the morphology in the periphery of the lateral branches of the dentinal tubules. The authors think that many investigators took no notice of these structures, as in most cases the histology of the dentin was investigated through decalcified sections, and undecalcified ground sections were considered to be less reliable to study.

Parallelity in the staining properties with the walls of the dentinal tubules. When stained the ground section with several methods, in some cases the globular structures appeared distinctly. In other cases these were obscure. With hematoxy- 
lin and MALLORY staining the structures in the tubular branches were clear enough to distinguish, and MANN's and SCHMORL's technique failed to clarify the structure. With the latter method the reddish coloured structures again disappeared at a prolonged differentiation with picric acid, and this is reasonable as the meehanism of SCHMORL's method is according to the writer himself (1928) not the staining proper but the precipitation of minute dye particles.

The reason why these differences were set forth was caused by the difference of the affinity of the dye to the globular structures. The dye which has the affinity to the gloubular structures seems to have the affinity to the wall of the dentin tubes too, and what gives a weak reaction to the wall of the dentin tubules seems to fail to show the globular structures. With MALLORY staining the dentinal fiber was a blue and the wall of the dentinal tubules was a pronounced reddishpurple, that was rather similar to the red globular structures. At this point, similarity of the chemical composition between either structures is to be supposed.

WISLOCKI, SINGER and WALDO (1948) extensively studied the histochemistry of the tooth and stated that the metachromatic substance occurring in the walls of the dentinal tubules was composed of a sulphated mucopolysaccharide, as the basophilic staining disappeared between $\mathrm{pH} 2.5$ and 3 . J.S. KENNEDY and G. D. C. KENNEDY (1957) ascertained this fact embryologically from the investigations with Isotope $S_{35}$.

The upper descriptions are suggestive of the presence of a sulphated mucopolysaccharide in the globular structures, but the existence could not be assured by the lack of evidence. Although toluidine blue staining in a ground section showed as if the globular structures are stained metachromatically, the ground sections were somewhat too thick to signify the fact as already WISLOCKI et al. mentioned. DEMPSEY, BUNTING, SINGER and WISLOCKI's methylen blue extinction test (1947) are to be cautiously estimated in the ground section as well as metachromatic reaction.

The reason why the globular structures are unstained in the decalcified section is not clear enough to determine whether it is by the loss of some organic elements during the decalcification process, or merely by the difference of the chemical composition of inorganic substances of the dentin matrix. In the latter case, mucopolysaccharide or sulf hydril groups seem not to be contained in the globular structures from the beginning.

Relationship between the globular structures and inorganic elements of the matrix of the dentin. As already stated, inorganic salts forming the mineralized tissues, when the histological demonstration of calcium ion are positive, are in a more reactive and less crystalline form. It should be noted also that OMORI applied Nagase (a sort of protease) to the ground section for 35 days, followed by staining with eriochrome black $\mathrm{T}$ : 1-(1-hydroxy-2-naphthylazo)-5-nitro-2naphthol-4-sulfonic acid sodium salt (KAUFMAN et al. 1954)*. to show the glo-

* A chelate compound. The speficifity and the exactness of the positive regions are superior, but the sensitivity inferior to allizarin red S. Obtainable at the WAKO Junyaku, Tokyo. 
bular structure in the peripheral zone of the tubular branches. This means that in the globular structures the protein particles of the matrix loosely combines with the inorganic apatite crystals.

Presence of lipids in the matrix of the dentin. It is interesting that in the matrix around the lateral branches of the dentinal tubules are abundant in sudan black B positive globular structures. AKAMATSU (1929) showed the presence of lipids in the ground substance of the dentin of the carious and hypoplastic tooth, and BARGMANN (1934) in the intact tooth of rhesus monkey. WISLOCKI et al. (1950, 1948), using sudan black B, did not mention the presence of lipids in the dentinal matrix. The authors have succeeded to demonstrate lipids in the interglobular spaces and in the walls of the dentinal tubules on ground and frozen-sections, thought much weaker than the dentin fibers. At the same time, the globular structures, especially around the dentino-enamel junction, appeared black with the dye. As lipids in the dentinal matrix are derived from the dentinal fibers as stated by BARGMANN, the globular structure in the matrix might have the metabolic interrelationship with the dentinal fibers.

Summary. Observations of undecalcified ground section reveals that in the matrix surrounding the lateral branches of the dentinal tubules are globular structures composed of less crystallized calcium salts. As decalcified sections fail to demonstrate this globular structures, organic elements of the matrix of dentin do not give any variations, but are probable to have some. The presence of lipids is to be supposed the metabolic interrelationship with the dentinal fibers. Summarising all these facts the globular structures seem to be advantageous structures for the dentin to take metabolic activities through the dentinal fibers.

\section{Conclusions.}

1. Observations of acid-etched ground sections with phase contrast microscope show that in the surroundings of lateral branches of the dentinal tubules are globular structures present.

2. A certain dye which has an affinity to the walls of the dentinal tubules can demonstrate the globular structures, as well.

3. Histochemical method for the ionizable calcium salts reveals positive in the globular structures, and therefore the structures are more reactive and less crystallized.

4. As decalcified sections fail to demonstrate the st:ucture, any variations in the organic elements of the matrix can not be perceived, but are possible.

5. The presence of lipids suggest the metabolic interrelationship with the dentinal fibers.

6. The globular structures seem to be advantageous structures for the dentin to take metabolic activities.

Acknowledgement. The authors heartly express those thanks to Prof. V. MIZUHIRA for his leaderships, to Prof. S. ARAYA and Dr. I. OMORI of the department of biochemistry of the Tokyo Medical and Dental University for giving the opportunity of observing their precious specimens, and to Dr. S. ITAGAKI for the offer of material. 


\section{内容自抄。}

水平は歯牙の不染研磿標本を位相差顕微鏡で観察中，偶々，象牙細管の側枝の 末梢附近に球状の構造物のあることを見出した。

この構造物が光学的偽像，或いはとの他の原因によってこの様に兒えるすのか， 正常の構造物であるかを決定する為に組織化学的検索を加味して研究を行った.

ヘマトキシリン染色，Mallory 染色等の㫮通染色では，象牙細管壁治強い親和 性のある色素のみが球状構造を現出し得る.

結晶度の低いカルンウム塭の組織化学的証明法である Kossa 法, 或いはアリ ザリンーレッド -S 法で球状棈造が明らかとなるので，この部分は不灰化が羊れ て結晶度が低いものから成立っている構造であることが明らかである。

脱尒奵片飞就いてはわれわれが行った如们なる染出法によっても球状構造は部: 明出来なかった，從って球状棈造の部分の有機些基質飞変化があることは訨明し

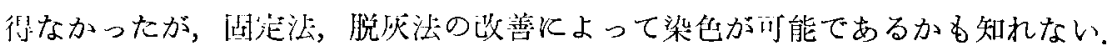

ズダンブラック B 法炕よって球状構造は著明飞現出し得る。この事は脂肪坐 要素の多い象牙線維との閏何等かの物質父流があり得ること交す。

以上の諸点より象牙維管の㑬枝の未梢にある球状構造物が象牙質の代锹飞何管: かの役㓶を果しているであろうことが推察せられた。

\section{References.}

A kamatsu, K. : Das Vorkommen von Fett im Schmelz des Zahnes. Vierteljahrschr. Zahnheilk. 45 (1929). S. 33-47. - Bargmann, W.: Zur Histologie des Dentins. Z. Zellforsch. 20 (1934). S. 442-458. - Barnett, R. J. a. A. M. Seligman: Histochemical demonstration of protein-bound sulfhydryl groups. Science. 116 (1952). P.323-327.- Histochemical demonstration of sulfhydryl and disulfide groups of protein. J. Nat. Cancer Inst. 14(1954). P. 769 -804. Cason, J. E. : A rapid one step Mallory-Heidenhein stain for connective tissue. Stain Technol. 25 (1950). P. 225-226. - Chèvremont, M. et J. Frederic: Une nouvelle méthode histochimique de mise en évidence des substances à fonction sulfhydrile. Application à l'épiderme, au poil et à la lavure. Arch. de Biol. 54 (1943). P. $589-605$ - Dahl, L. K. : A simple and sensitive histochemical method for calcium. Proc. Soc. exp. Biol. Med. 80 (1952). P. 474-479. - Dempsey, E. W., H. Bunting, M. Singer a. G. B. Wislocki : The dyebinding properties of mammalian mucopolysaccharides. Anat. Rec., 98 (1947). P. 417-430. - Fujita, T.: Ha no soshikigaku. (Jap.) 'Tokyo, Ishiyaku-Schuppan, 1957. - Gomori, G. : Microscopic histochemistry. New York, Univ. Chicago Press, 1952. - Heller.Steinberg, M. : Ground substance, bone salts, and cellular activity in bone formation and destruction. Amer. J. Anat. 89 (1951). P. 347-379. - Harms, H. : Handbuch der Farbstuoff für die Mikroskopie. Teil 2, 1. Lfg. 1957. - Kaufman, H. E. a. E. C. Adams : Water-soluble chelates in histochemical staining. Science, 120 (1954). P. $723-724$. -. Kennedy, J. S. a. G. D. C. Kennedy : Sulphated mucopolysaccharides in rodent teeth. J. Anat. 91 (1957). P. 398-408. - Lison, L. : Histochimie et cytochimie animales. Paris, Gauthier-Villars, 1953. - McConnaill, M. A. : The fibers in dentinal tubules. J. Anat., 89 (1955). P. 569. - McLean, F. C. a. W. Bloom : Calcification and ossification. Calcification in normal growing bone. Anat. Rec. 78 (1940), P. 333-359. - Mizuhira, V.: 
Shika ni okeru isōsa kenbikyō no ōyō. Shika Kõkūgeka Saikin no Shinpo. (Jap.) Tokyo, Ishiyaku-Shuppan, 1956. P. 85-124. - 1958. In preparation. - Ömori, I. : Personal communication. -Orban, B. : Oral histology and embryology. 3rd Ed., St. Louis, Mosby, 1953. Pearse, A. G. E. : Histochemistry. London, J. and A. Churchill, 1953. - Richards, O. W.: In 'Phase Microscopy' by A. H. Bennet, H. Jupnik, H. Osterberg and O. W. Richards. New York, Wiley \& Sons, Inc., 1951. - Romeis, B.: Tasehenbuch der mikroskopischen Technik. 15. Aufl. München, Leibniz verlag, 1948. - Sch morl, G.: Die pathologisch-histologischen Untersuchungsmethoden. Leipzig, F. W. C. Vogel, 1928, - Sognnaes, R. F.: Microstructure and histochemical characteristics of the mineralized tissues. Ann. N. Y. Acad. Sci. 60 (1955). P. 545-574. - Tomes, C. S. : A manual of dental anatomy. London, J. \& A. Churchill, 1923. - Wislocki, G. B., M. Singer a. C. M. Waldo : Some histochemical reactions of mucopolysaccharides, glycogen, lipids and other substances in teeth. Anat. Rec. 101 (1948). P. 487-514. - Wislocki, G. B., a. R. F. Sognnaes : Histochemical reactions of normal teeth. Amer. J. Anat. 87 (1950). P. 239--275. 